\title{
Wave loading on rock lighthouses
}

1 Alison Raby BSC, PhD, DPhi Reader, School of Marine Science and Engineering, Plymouth University, Plymouth, UK

2 Geoffrey N. Bullock BSC, PhD, CEng, MICE (Retd.) Emeritus Professor, School of Marine Science and Engineering, Plymouth University, Plymouth, UK

3 Davide Banfi Ing PhD Student, School of Marine Science and Engineering, Plymouth University, Plymouth, UK
4 Yaqub Rafiq BSc, MSc, PhD, CEng, MlstructE, MASCE, FHEA Senior Lecturer, School of Marine Science and Engineering, Plymouth University, Plymouth, UK

5 Federico Cali Ing

Former MSc Student, School of Marine Science and Engineering, Plymouth University, Plymouth, UK
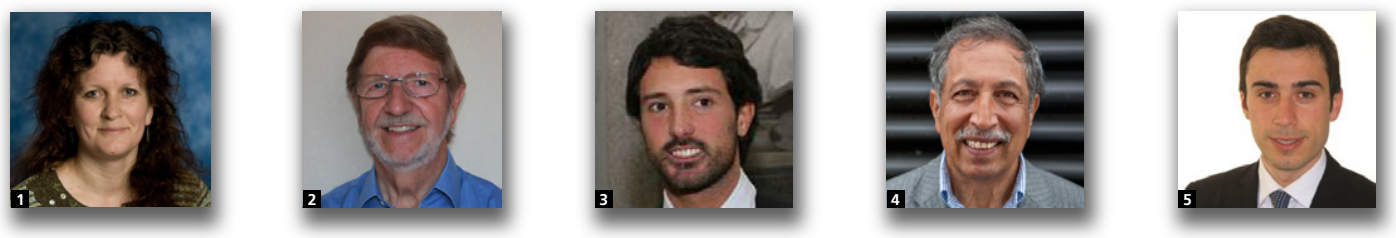

Historical and contemporary observations of wave-impact loading on rock lighthouses during storms are presented. With climate change potentially causing sea level rise and more energetic wave climates, the longevity of these heritage structures cannot be taken for granted. To obtain a better understanding of the wave-structure interaction, Plymouth University has been working with the General Lighthouse Authorities to develop monitoring and modelling techniques suitable for these isolated masonry structures. Details of the field campaign, in which 2978 impact events were recorded during the winter storms of 2013/2014, are presented together with an initial analysis that begins to shed light on the dynamic response of these iconic structures. The results indicate that the response can be sensitive to the type of wave impact and that the overall motion of the Eddystone tower was less than might have been expected. A finite-element model of the tower was able to reproduce accurately the frequencies of the first and third modes of vibration but, unlike the field data, failed to show response at a frequency near the second mode. Preliminary attempts to apply wave loads estimated on the basis of ISO 21650 show reasonable agreement between the model displacements and those measured.

\section{Notation}

$H_{\max } \quad$ maximum wave height

$H_{\mathrm{s}} \quad$ significant wave height

$T_{\mathrm{p}} \quad$ period associated with the peak of wave energy spectrum

\section{Introduction}

There are about 20 masonry lighthouses around the UK that are exposed to wave action. The locations of three of the most exposed (Wolf Rock, Longships and Eddystone) are shown in Figure 1.

The perilous Eddystone reef, some 14 miles $(22.53 \mathrm{~km})$ off Plymouth, gained its first lighthouse in 1698. This stone-clad wooden structure was swept away by the great storm of 1703 .
Three further lighthouses have stood at that location, each larger and more sturdy than its predecessor. The structure designed by Smeaton represented a major advance in the art of civil engineering and is featured in the Institution of Civil Engineers' coat of arms. It was replaced by the present lighthouse, the Douglass tower, in 1882 (Figure 2).

Although mariners are making ever greater use of satellitebased navigation technologies, the General Lighthouse Authorities (the umbrella organisation of Trinity House, the Northern Lighthouse Board and the Commissioners for Irish Lights) recognises the need to retain rock lighthouses as physical aids to navigation. However, there is concern about how well they would withstand the additional wave loading associated with predicted sea level rises and increased 


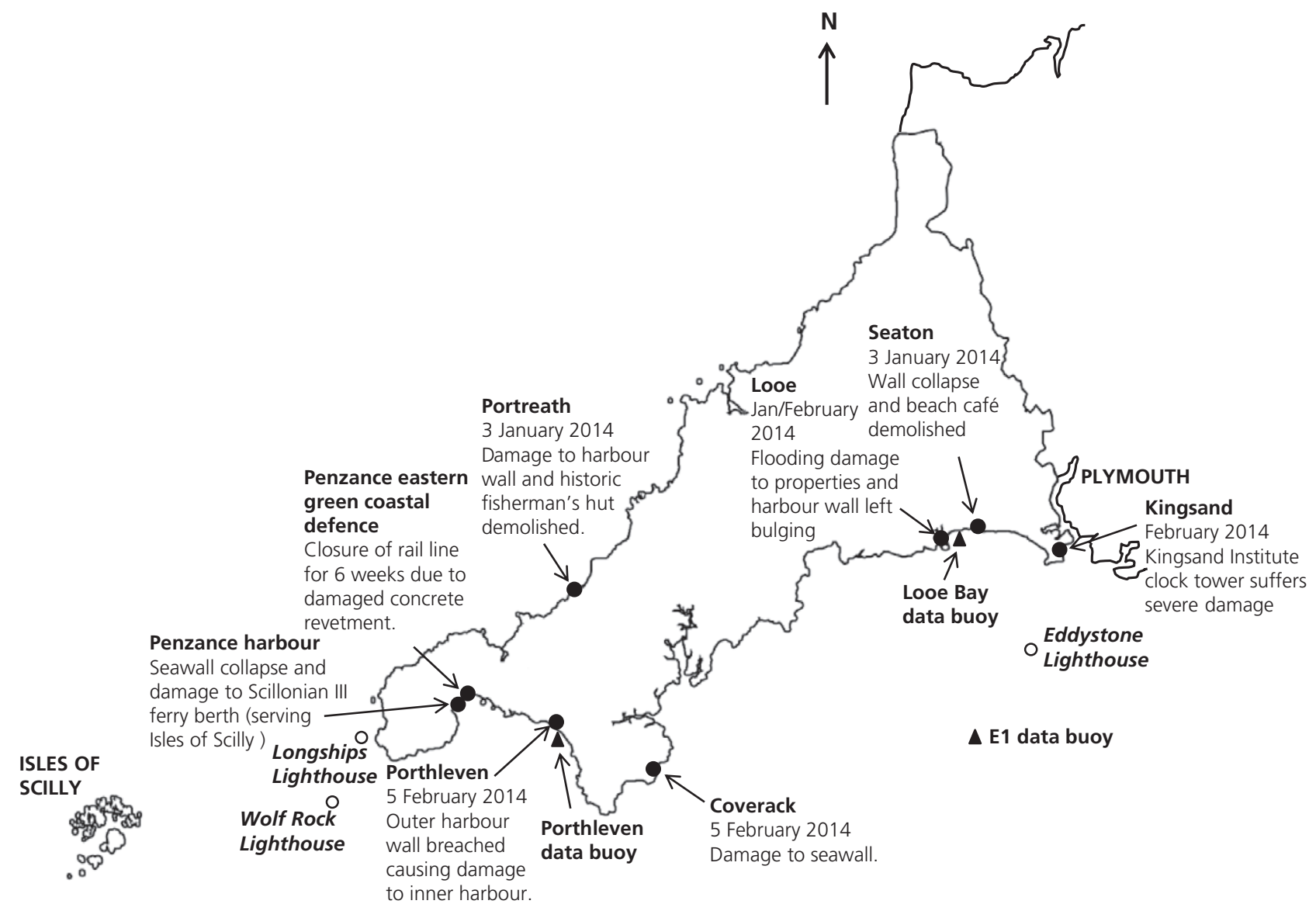

Figure 1. Locations of storm damage, lighthouses and wave buoys in Cornwall

storminess. The UK planning policy statement 25 (Planning Portal, 2010), produced by the Department for Communities and Local Government includes isostatic subsidence in its predictions and has recommended contingency allowances for sea level rise in the southwest of $3.5 \mathrm{~mm} /$ year from 1990 to $2025,8.0 \mathrm{~mm} /$ year from 2025 to $2055,11.5 \mathrm{~mm} /$ year from 2055 to 2085 and $14.5 \mathrm{~mm} /$ year from 2085 to 2115 . This gives a net sea level rise from 2009 levels of $0.786 \mathrm{~m}$ by 2095 . The UK planning policy statement 25 (Planning Portal, 2010) also provides national precautionary sensitivity ranges for extreme wave heights, suggesting that a factor of $+5 \%$ is applied from 1990 to 2055 , increasing to $+10 \%$ for 2055 to 2115.

Victorian engineers expended considerable effort on trying to assess the wave loading on their maritime structures, and constructed lighthouses so durable that little thought had to be given to their behaviour under extreme conditions until now. Section 2 of this paper contrasts what the Victorians knew about the wave environment with what is now known.
Section 3 describes the instrumentation that was installed on the Eddystone Lighthouse to record both the waves that reached the structure and its response. Section 4 outlines details of a finite-element (FE) model of the Eddystone Lighthouse. Section 5 presents the data acquired during the winter storms of 2013/2014 that had such a devastating effect in the southwest of England, as outlined in Figure 1. Section 6 provides concluding remarks.

\section{Wave loading on exposed maritime structures}

\subsection{Historical approach}

Much of the early work on understanding wave loading was undertaken by the Stevensons, the family of lighthouse builders responsible for building all the rock lighthouses around the coast of Scotland over four generations (Bathhurst, 2005). Robert Stevenson (grandfather of the author Robert Louis Stevenson) provides a descriptive view of the waves interacting with the Bell Rock Lighthouse in Scotland. He describes how 


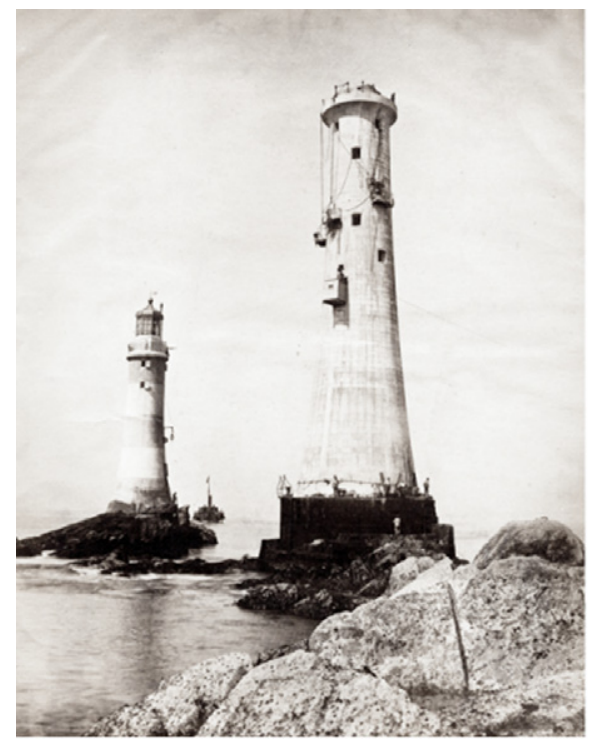

(a)

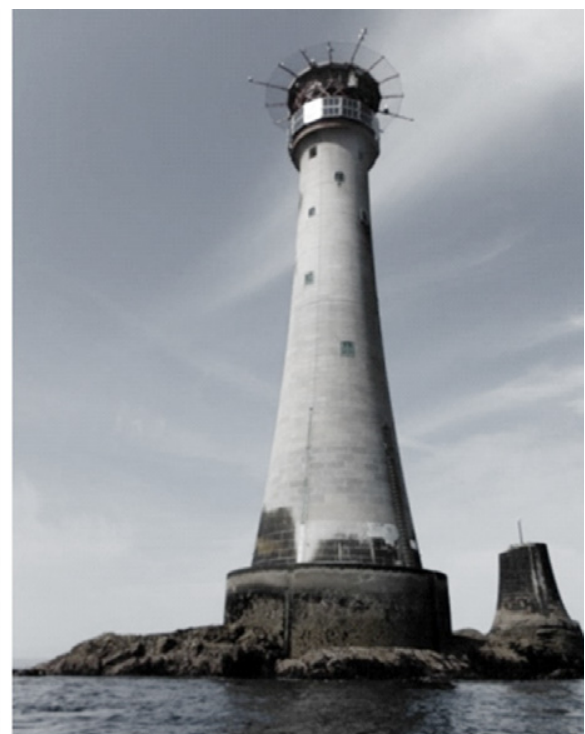

(b)

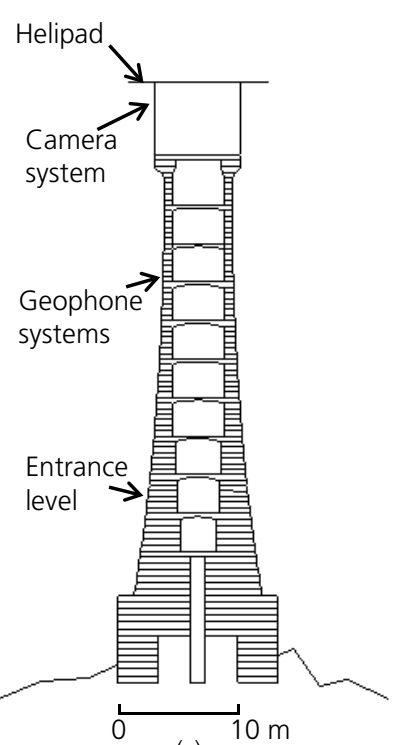

(c)
Figure 2. Eddystone lighthouses: (a) photograph of the construction of the Douglass tower in the foreground and the Smeaton tower in the background, taken c. 1880-1881, reproduced by kind permission of ICE; (b) the Douglass tower in
2013 with the stump of the Smeaton tower to the right, reproduced by kind permission of $\mathrm{M}$. Docker; and (c) outline of the Eddystone Lighthouse showing the masonry courses, internal spaces and the locations of the deployed instruments in some circumstances the door could be left open without fear of water ingress despite big seas

\footnotetext{
... the waves separate below, and are sent round the building with such force, that their collision upon the lee-side produces ... a downy spray, white as snow, rises at some distance from the house, to the height of 20 or 30 feet above the medium surface of the sea, and comes in minute particles upon those within the entrance-door, producing a sensation as if dust were falling upon them.

(Stevenson, 1824)
}

At the Eddystone the wave climate is affected by the complex three-fingered reef and a tidal range that can exceed $5 \mathrm{~m}$. During construction of the lighthouses there were constant delays due to the inability to land on the reef even during calm summer weather. Winstanley (1699), who built the first tower, is quoted (Majdalany, 1959) as saying that

... though the weather should seem to be most calm in other places, yet here it would mount and fly more than two hundred foot ...

Smeaton, who designed the third lighthouse, made the observation that 'on a perfectly calm day, with the water for half a mile around seemingly as smooth as glass, a scarcely perceptible ground swell could send an unexpected wave billowing over the rock, even though its peak was at the time nine feet above water level' (Majdalany, 1959). Smeaton made further interesting observations that during periods of 'comparatively innocuous swell' waves could be sent up to a height of around $10 \mathrm{~m}$ or so as they broke at low tide on the western end of the reef, although at high tide the same was not witnessed even though the swell was much greater (Majdalany, 1959).

In their search for knowledge, the Victorian pioneers were quite prepared to draw on the experience of others. Thus, a circular letter was sent to lighthouse keepers asking them to find out from the 'oldest and most intelligent fishermen' which wind directions caused the 'heaviest seas' and to complement this with their own views. One recorded observation concerning the height of the spray at the Bell Rock states that it reached between 60 and $80 \mathrm{ft}$ (18-24 m) during February 1845 (Stevenson, 1848).

Quantitative estimations of wave height were attempted at Skerryvore in Scotland by fixing a graduated pole to a nearby submerged rock. Unsurprisingly it was found that 'observances were not of so satisfactory a nature' due to the fact that 'the poles soon worked loose from their attachments, and disappeared' (Stevenson, 1848).

\subsubsection{The marine dynamometer}

Frustration at the paucity of wave loading knowledge is reflected in the comments of Alan Stevenson (1848)

We have little more than conjecture to guide us ... to estimate the power or intensity to which Sea Towers are subject ... The only 


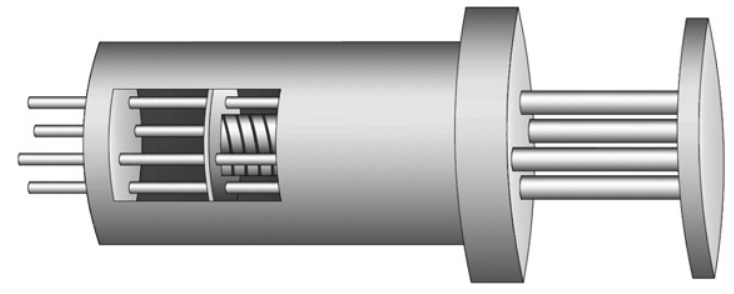

Figure 3. Thomas Stevenson's marine dynamometer based on a sketch in Stevenson (1848)

experiments ... are those of Mr Thomas Stevenson, Civil-Engineer, who had long entertained the idea of registering the force of the impulse of the waves, and lately contrived an instrument for the purpose, which he has applied at various parts of the coast.

The marine dynamometer, as it was called, was an ingenious device designed to measure the maximum wave-impact pressure at a particular location. It was constructed from cast iron and securely bolted to the reef so that the plate shown to the right in Figure 3 faced the approaching waves. Each wave impact on the plate then pushed rods through the cylindrical body of the device against the resistance of the set of springs housed inside it. Small leather rings on the rods indicated the maximum displacement, which, together with knowledge of the springs' stiffness, enabled the pressure on the plate to be estimated. Some redundancy in the number of guide rods gave confidence that the leather rings had kept their maximum positions. Individual pressure readings at a specific location would therefore be available from a storm, once conditions permitted the lighthouse keeper to access the instrument.

Extensive experimentation in the placement and design of the dynamometer was undertaken. In some situations the size of the plate had to be reduced and/or the stiffness of the springs increased because the impact pressures were too large. As a quality check two devices were placed side by side and maximum pressures were found to be within $1 \%$ of each other. The effect of placing devices at different elevations was also explored. Over a period of some 23 months, Thomas Stevenson used three of his dynamometers to obtain the world's first set of systematic measurements of wave-impact pressures. Given the importance of estimating forces, he recognised that his methodology should not be restricted to lighthouses, but was also applicable to other 'seaworks' such as breakwaters.

The first four columns of data in Table 1 have been taken directly from Stevenson (1848), where instrument I was placed 'several feet lower' and 'about 40 foot seaward' of instrument II, which was closest to the lighthouse. Evident from Table 1 is that the device placed closest to the tower and

\begin{tabular}{|c|c|c|c|c|}
\hline Date & Remarks & $\begin{array}{l}\text { No. of } \\
\text { instrument }\end{array}$ & $\begin{array}{c}\text { Pressure: } \\
\mathrm{kN} / \mathrm{m}^{2}\end{array}$ & $\begin{array}{c}\text { Pressure: } \\
\mathrm{kN} / \mathrm{m}^{2}\end{array}$ \\
\hline \multirow[t]{2}{*}{ Jan. 7} & Heavy sea & । & 1714 & 82 \\
\hline & & $\|$ & 4182 & 200 \\
\hline \multirow[t]{2}{*}{ Jan. 12} & Very heavy swell & I & 2856 & 137 \\
\hline & & $\|$ & 5032 & 241 \\
\hline \multirow[t]{2}{*}{ Jan. 16} & Heavy ground & I & 2856 & 137 \\
\hline & swell & $\|$ & 4752 & 228 \\
\hline \multirow[t]{2}{*}{ Jan. 22} & A good deal of & I & 2856 & 137 \\
\hline & sea & $\|$ & 5323 & 255 \\
\hline \multirow[t]{2}{*}{ Jan. 28} & Heavy ground & 1 & 2627 & 126 \\
\hline & swell & $\|$ & 4562 & 218 \\
\hline \multirow[t]{2}{*}{ Feb. 5} & Fresh gales & 1 & 856 & 41 \\
\hline & & $\|$ & 3042 & 146 \\
\hline \multirow[t]{2}{*}{ Feb. 21} & & 1 & 1827 & 87 \\
\hline & & $\|$ & 3422 & 164 \\
\hline \multirow[t]{2}{*}{ Feb. 24} & Fresh breezes & 1 & 1256 & 60 \\
\hline & & $\|$ & 3802 & 182 \\
\hline
\end{tabular}

Table 1. Pressure readings from Skerryvore Lighthouse in 1848 (Stevenson, 1848)

at the elevated level recorded higher pressures. This may be related to a comment that Stevenson makes on how the state of the tide affects the reading, with low tides reducing the water that makes it over the reef.

\subsubsection{Structural response observations}

Attempts to estimate wave loads were enhanced by observations of how lighthouses behaved during violent storms. In respect of the Bell Rock Lighthouse, Robert Stevenson (Stevenson, 1824) reports that the keepers were startled by one particular wave impact while they were in the kitchen, fairly low down the tower. This impact was accompanied by a noise similar to that of a gun discharging and caused the doors to rattle. The keepers' first thought was that the tower must have been struck by a vessel, but this was quickly ruled out. Reflecting on these observations, Stevenson suggests that they may have been caused by a 'disturbance in the equilibrium of the air' resulting from the wave rushing up the outside of the tower. He further likens tremors experienced higher up the tower as not being dissimilar to the effect of a normal house door being slammed or a carriage of the time 'making a rattling noise in passing along the street'. On another occasion at Bell Rock, Professor John Robison, a renowned professor of natural philosophy (physics) at the University of Edinburgh, was sitting in one of the rooms in the lighthouse when the structure was hit by a violent wave. The impact caused a vibratory motion following which Robison assured others that the vibration was 'the strongest proof of the unity and connection of the fabric in all its parts' (Stevenson, 1824). 
Majdalany (1959) recounts many tales concerning the behaviour of the early Eddystone lighthouses. For example, Winstanley's structure was said to rock so much that crockery could be shaken from the table and the lighthouse keepers made seasick. Rudyard's tower, the second on the Eddystone reef, was also said to vibrate enough not only to shake utensils off surfaces but also to rock men out of their bunks. The principal keeper's log indicates that even Smeaton's tower could have a noticeable response to wave impacts. The report for a particularly violent storm states that it caused 'considerable motion of the cylinder glasses fixed in the lamps' and describes how the tower appeared to 'jump as if resting on an elastic body'.

Smeaton's lighthouse was replaced mainly because the gneiss rock on which it stood had been eroded. James Douglass (Douglass, 1878) also drew attention to the fact that storm waves could rise up the tower 'considerably above the summit of the lantern, thus frequently eclipsing the light and altering its distinctive character'; an impressive feat given that the focal plane of the light was $72 \mathrm{ft}(\sim 23 \mathrm{~m})$ above high water level. Furthermore, when the upward jet of water hit the projecting cornice just below the lantern (see Figure 2(a)) it 'lifted the portion of the building above this level'; a problem that was eventually solved by reducing the projection by 5 in $(\sim 130 \mathrm{~mm})$ and adding bolts to the wrought-iron ties that had already been installed in an attempt to stop the joints in the masonry near the top of the tower from opening.

William Douglass (1883) explained how his father, now Sir James, reduced the height of wave uprush on his lighthouse by founding it on a $22 \mathrm{ft}(\sim 6.7 \mathrm{~m})$ high by $44 \mathrm{ft}(\sim 13.4 \mathrm{~m})$ dia. cylindrical base. This, together with the tower it supported, was constructed from 2171 granite blocks that were dovetailed together both horizontally and vertically. The resultant structure increased the elevation of the focal plane of the upper of two lights to $133 \mathrm{ft}(\sim 40.5 \mathrm{~m})$ above high water. Trinity House (2015) gives the height of the current light as $41 \mathrm{~m}$ above mean high water.

\subsection{A brief review of current measuring techniques and knowledge}

Equipment is now available for measuring the height of ocean waves from below, at or above the air-water interface. Accelerometer buoys are well suited for taking measurements at remote deep-water locations and one was moored near the Eddystone for extended periods between 1973 and 1981 (Draper, 1991). Thanks to the prevailing southwesterly winds and the long fetch of the English Channel, the maximum winter wave heights were found to exceed $3 \mathrm{~m}$ for $10 \%$ of the time with a 1:50 year maximum wave height greater than $20 \mathrm{~m}$. The E1 data buoy is of particular relevance to the present investigation as it provided the data presented in Figure 6 and Figure 8. This Western Channel Observatory autonomous buoy, operated by Plymouth Marine Laboratory, is located as shown in Figure 1.

Various pressure and force transducers can be adapted to measure wave loading in the field. The pressure aeration units developed by Bird et al. (1998) also enabled the level of aeration to be estimated. Bagnold (1939) was the first to provide scientific evidence of the importance of air when he found that waves breaking against a vertical wall in a laboratory channel tended to generate the highest impact pressures when they trapped a small pocket of air against the wall. It has subsequently been demonstrated that entrained air tends to reduce wave-impact pressures (Bullock et al., 2001). Despite this, pressures up to $775 \mathrm{kN} / \mathrm{m}^{2}$ have been recorded in the field (Bullock and Bredmose, 2010) and over $1 \mathrm{MN} / \mathrm{m}^{2}$ in largescale laboratory tests (Bullock et al., 2007).

Even in well-controlled laboratory tests (e.g. Bagnold, 1939; Bullock et al., 2007) wave-impact pressures are highly sensitive to small differences in the breaking wave's profile. This makes detailed analysis of results obtained from physical tests extremely difficult. Numerical models provide a means of gaining insight into the physics, and it has been shown that the pressure waves emanating from the impact zone can become shock waves in the most extreme cases (Bredmose et al., 2009). Entrained air has also been shown to play a pivotal role in reducing impact pressures (Bredmose et al., 2015), and it is fortunate that entrained air tends to persist in full-scale waves for longer than suggested by small-scale model tests (Blenkinsopp and Chaplin, 2011).

Because wave-impact pressures tend to be both spatially and temporally localised (Bullock et al., 2001, 2007), it was sometimes thought that the resultant impulses were of too short a duration to displace large structures. However, since Oumeraci (1994) attributed a number of breakwater failures to breaking waves, it has become common practice in Japan to assess the expected sliding distance of breakwaters (Goda, 2010).

The installation of offshore wind turbines on monopoles has led to renewed interest in the loading and run-up of breaking waves on cylindrical structures (Bredmose et al., 2006). Other findings, including those arising from interest in oil platforms, included confirmation of the variability of impacts (Chan et al., 1995; Lykke Andersen et al., 2011), the importance of breaking wave type to the resulting impact (Chan et al., 1995; Wienke and Oumeraci, 2005) and their spatially localised nature (De Vos et al., 2007; Kyte and Tørum, 1996). Also of great relevance to rock lighthouses has been the work to investigate the role of bathymetry, specifically reefs, into the wave transformation and subsequent impact (e.g. Mase et al., 2001). However, the authors are not aware of any modern research, at 
either model or full scale, into the wave loading on tapered structures such as lighthouses.

\section{Instrumentation of the Eddystone Lighthouse}

As a precursor to a more detailed investigation into the relationship between wave loading and the structural response of more vulnerable masonry lighthouses, equipment was installed on the Douglass tower to understand better the magnitude and direction of incoming waves and to see if it would be possible to record the subsequent motion of the tower. The choice of equipment was constrained by a number of factors including

- power availability limited to $300 \mathrm{~W}$ for $1 \mathrm{~h}$ periods and a maximum total energy of about $260 \mathrm{kWh}$ over a year, due to all power being generated by photovoltaic panels with diesel generator back-up

- the inability to access instrumentation between the two or three short annual maintenance visits by helicopter of Trinity House staff

- the difficulty of attaching anything to the outside of the masonry structure

- the hostile wave climate at the reef.

These factors effectively rule out a conventional wave loading field campaign that would measure surface elevations within close proximity of the structure using bottom-mounted pressure transducers or wave buoys, and would obtain localised impact pressures using ruggedised pressure transducers. Given the highly localised nature of the wave impacts mentioned previously, it would also be impractical to install enough transducers to get a clear indication of the overall pressure distribution.

Instead, both to satisfy the constraints and facilitate regular monitoring, it was decided to use remote-controlled, DCpowered video cameras to record the wave conditions around the structure, together with two RDL//Vibe geophone systems to measure any structural response. The use of two geophone systems provided data quality checks and some redundancy. The equipment was installed in the arrangement shown schematically in Figure 4, during a $48 \mathrm{~h}$ visit to the lighthouse by two members of staff from Plymouth University in the summer of 2013 .

\subsection{Camera system}

Four cameras were attached to the helideck structure at the intermediate platform level as indicated in Figure 2(c). One of the cameras was angled towards the 'far field' to provide information about wave transformation across the reef, while the others looked down at the waves reaching the lighthouse from the three directions listed in Table 2. All the cameras were

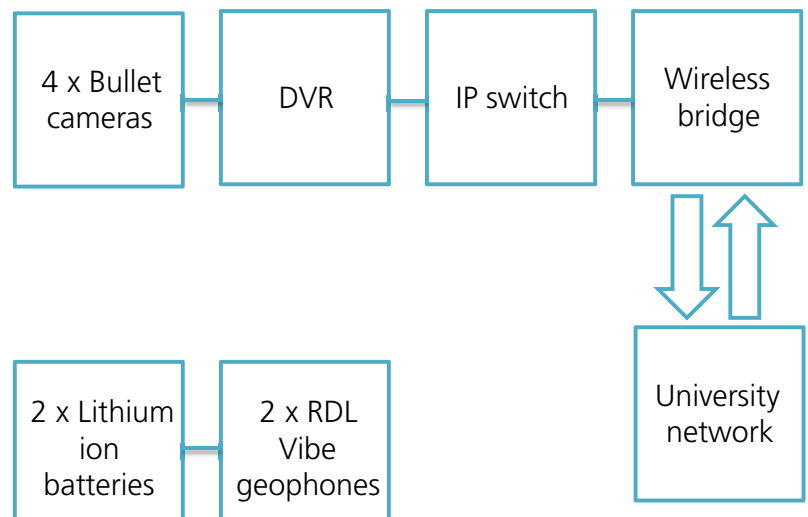

(a)

\begin{tabular}{lll}
\hline Camera no. & Direction & Near or far-field \\
\hline 1 & SW $\left(225^{\circ}\right)$ & Far \\
2 & NNW $\left(337 \cdot 5^{\circ}\right)$ & Near \\
3 & ESE $\left(112 \cdot 5^{\circ}\right)$ & Near \\
4 & SW $\left(225^{\circ}\right)$ & Near
\end{tabular}

Table 2. Orientation of cameras

linked to a digital video recorder controlled by an internet protocol switch accessed by way of a line of sight wireless bridge to the Plymouth University campus.

To avoid wasting power and data storage, the camera system was set to be off between the hours of 22:00 GMT and 04:00 GMT and was not switched on during calm conditions. It was only switched on after an alert based on data from the Channel Coastal Observatory (CCO) indicated that the significant wave height at the Porthleven, Looe Bay (see Figure 1) or the (South Devon) Start Bay wave buoy exceeded $1.5 \mathrm{~m}$. Because impacts were rarely, if ever, recorded at that wave height threshold, the cameras were not automatically switched on, but the alert was taken as a forewarning of potential activity. 
When on, the cameras would normally capture video images at a rate of 1 frame/s. A region at the base of the tower in each near-field image was also monitored for activity typical of a wave running up the structure. When this happened the cameras acquired data at 5 frames/s for a period of at least $30 \mathrm{~s}$ and continued at this higher recording rate while evidence of run-up in that region persisted.

Although the system was designed to enable remote downloading of the data, this was rarely undertaken as it took approximately $1 \mathrm{~min}$ to download $1 \mathrm{~s}$ of video image. Consequently, most of the data were analysed after swapping the digital video recorder hard drives during visits to the lighthouse. This further constrained the time that the cameras could be on as the hard drives could only store 1862 GB of data, which corresponds to about $994 \mathrm{~h}$ of recording at the higher rate.

Assessment of the wave loading on the lighthouse was based on the statistical wave parameters obtained from the E1 buoy and the heights of individual wave run-up events estimated from the distorted images captured by the video cameras. To improve the accuracy of the estimates, a geo-referenced grid was established for images of the tower by holding targets at known elevations out of windows. With appropriate processing, the elevations of the masonry courses could then be determined and a correcting grid produced. However, nothing could be done to reduce the errors introduced by poor light and white water.

\subsection{Geophone system}

Geophone systems are normally used to acquire the velocity time history of seismic disturbances, and are activated when a disturbance exceeds a set threshold level. The data can then be integrated or differentiated to obtain displacements and accelerations, respectively.

The two systems used to monitor the vibration of the tower were installed in the subsidiary light room on level LXX between the kitchen and bedroom levels, as shown in Figure 2(c). They communicated by way of the global system for mobile communications so that alerts could be received and data remotely downloaded. Data-acquisition features such as the threshold level and acquisition rate could also be changed without visiting the lighthouse.

\section{Finite-element modelling of the Eddystone Lighthouse}

In parallel with the field campaign, a structural model of the Eddystone Lighthouse was developed using an FE model (LUSAS v.15). Only the masonry portion of the lighthouse was modelled, fully fixed at its base, and the initial validation comprised comparisons with theory in increasing degrees of complexity: first an axisymmetric cylinder subjected to

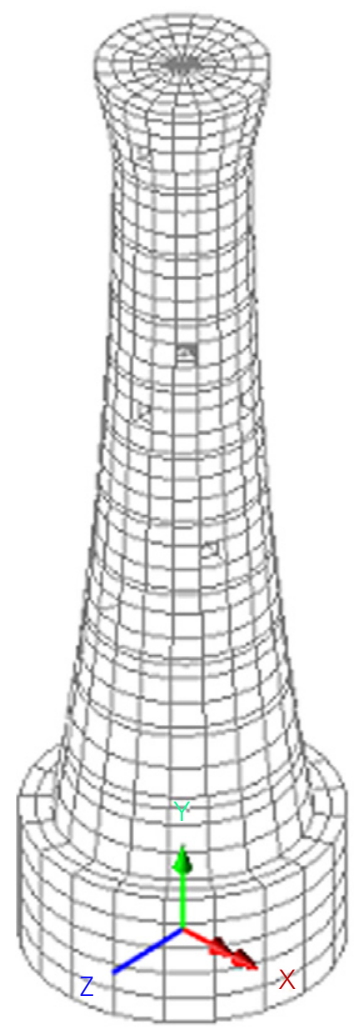

(a)

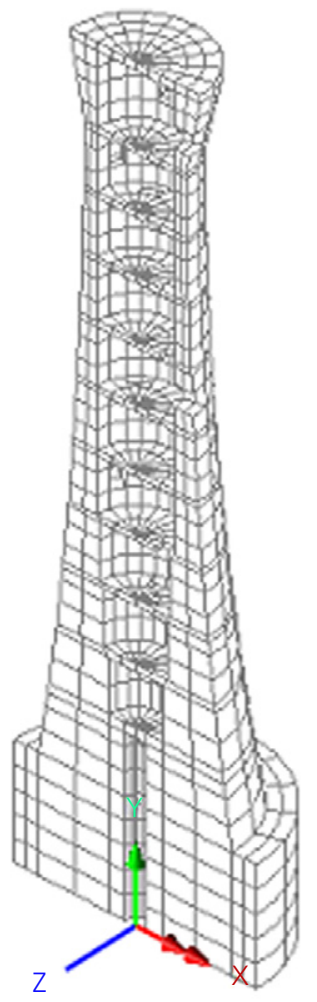

(b)
Figure 5. Finite-element model of the Eddystone Lighthouse: (a) full model and (b) symmetrical half model

self-weight compared with theory by Timoshenko and Goodier (1951); then a hollow cantilever beam displacement subjected to a uniformly distributed load (Capurso, 1971), and a single degree of freedom triangular impulsive load on a hollow cantilever beam (Clough and Penzien, 1993). Historic drawings of the lighthouse permitted a full representation of the tower as shown in Figure 5, with a solid core up to $4 \mathrm{~m}$ above the cylindrical plinth and then a hollow core with a tapering wall thickness of about $3.2 \mathrm{~m}$ reducing to about $0.7 \mathrm{~m}$. The FE model also included window openings. Mesh convergence tests determined the elements and order of interpolation and resulted in a model comprising hexahedral elements with a quadratic interpolation order and 15188 nodes.

According to Majdalany (1959), the lighthouse was built with granite from the quarries of De Lank in Cornwall and Dalbeattie in Scotland. Young's modulus values for those quarries was obtained as $32 \mathrm{GPa}$ and $40 \mathrm{GPa}$, respectively, and without further information on which of the blocks was used where, a mean value of $36 \mathrm{GPa}$ was used. Finally, the mass density of the blocks was assumed to be $2640 \mathrm{~kg} / \mathrm{m}^{3}$, the elastic tangent modulus $15 \mathrm{GPa}$ and the Poisson ratio $0 \cdot 2$. 
The full model of the tower provided vibration mode information. Deflections were also obtained by applying load curves to the nodes, as described in Section 5.3.

\section{Results}

Beginning a few days before Christmas 2013, the southwest of England experienced a sequence of 12 discrete storms resulting in the stormiest weather for 52 years (Owens, 2014). Key storm dates going back to October 2013 are shown in Figure 6 with further information in Figure 1. On 5 February 2014 the CCO wave buoy at Penzance $(\mathrm{CCO}, 2014)$ recorded a $21 \mathrm{~m}$ wave in the range of the 1 in 50 year wave given by Draper (1991). However, this was later identified as a data spike sometimes observed in high, steep seas when waves are breaking onto the buoy. Figure 6 , which presents $H_{\mathrm{s}}$ data from the E1 data buoy, gives a maximum $H_{\mathrm{s}}$ value of about $6.5 \mathrm{~m}$ for 5 February.

\subsection{Observations by lighthouse personnel}

Automation of lighthouses began in the 1980s and all lighthouses are now unmanned (Trinity House, 2014). However, Trinity House engineers happened to be carrying out maintenance on both the Bishop and Wolf Rock Lighthouses on 5 February 2014. Following the tradition of the early lighthouse keepers, their observations provide useful anecdotal evidence on the structural behaviour of the towers.

On Bishop Rock, the project engineer recounted that he and his colleagues were all awoken at about 3.00 a.m. by a severe wave impact. Several more notable impacts followed through the night. The largest impact was accompanied by a loud booming noise. Then an oscillation of the tower similar to a minor earthquake was experienced - perhaps three or four cycles with a period of a few (perhaps 3 to 4) seconds.

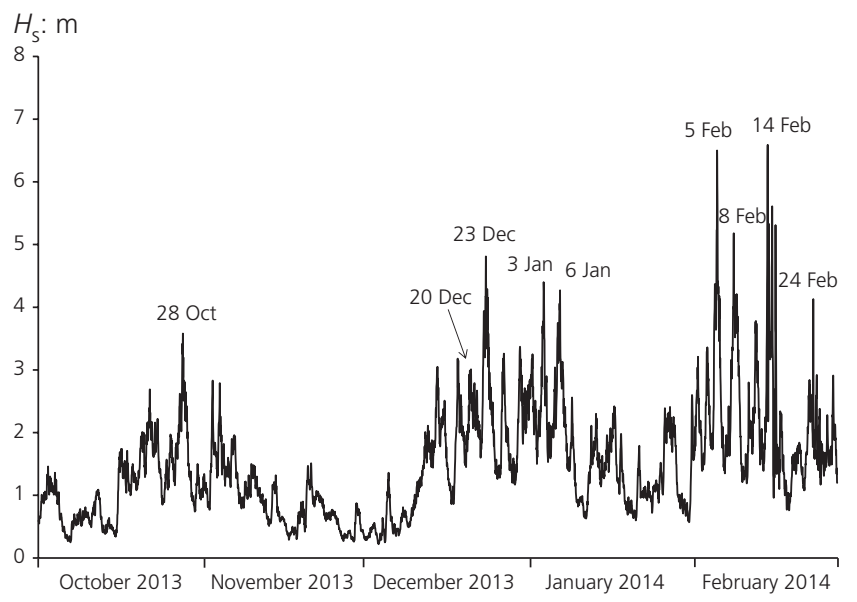

Figure 6. Hourly significant wave height from E1 data buoy with significant storms and dates indicated
A groaning noise accompanied the oscillations together with a rattling that may have been due to movement of fittings within the tower. During less extreme impacts, when the personnel were up and about, chinking of glasses in cupboards was heard and when seated the motion felt like a gentle rocking.

A lighthouse technician on Wolf Rock also awoke at 3.00 a.m. with the noise of crockery rattling on surfaces. He estimated the vibrations to have a period of around $10-15 \mathrm{~s}$, although these may have been confused with the interval between successive wave impacts. The noise of the wave impacts sounded like a car being crushed - a deep rolling rumbling noise with vibrations following. A sloshing motion was set up in the 2501 water tanks situated at the top of the tower, on the level under the lantern gallery. He noted the wind speed, as measured on an anemometer, recorded gusts of more than $100 \mathrm{mph}$ $(160.93 \mathrm{~km} / \mathrm{h})$, although it was typically $70-88 \mathrm{mph}(112.65$ $141.62 \mathrm{~km} / \mathrm{h}$ ). Finally, he commented that it was the worst storm he had experienced in 25 years of working on lighthouses.

\subsection{Video and geophone data}

Although the Met Office (2013) placed the St Jude storm of 28 October 2013 within the ten most severe autumn storms in southern England during the last 40 years, with wind gusting up to $99 \mathrm{mph}(159 \cdot 33 \mathrm{~km} / \mathrm{h})$ at the Needles on the Isle of Wight, the geophones on the Eddystone Lighthouse failed to register any structural response. However, any doubts about the ability of the geophones to detect structural motions evaporated on 20 December 2013 when further storms came in from the Atlantic providing data for 2978 individual vibration events between then and 14 March 2014. Looking back at Figure 6 , it is evident that the significant wave height on 28 October only reached about $2.5 \mathrm{~m}$. The fact that the storm was a fast-moving depression that passed through during low tide probably explains the discrepancy between the strength of the wind and the size of the waves and hence the lack of registered impacts on the lighthouse. This is confirmed by the impact data, which suggest that impacts occur when the significant wave height exceeds $2 \mathrm{~m}$ for more than 6-12 h and particularly when large waves coincide with high tide.

Figure 7 shows a histogram of the maximum velocities measured by the geophone during each of the 2978 events. A broken vertical axis is used due to the fact that events are very heavily weighted to smaller events in the first bins. In fact only 14 events caused the maximum velocity to exceed $4 \mathrm{~mm} / \mathrm{s}$ (eight at $4-5 \mathrm{~mm} / \mathrm{s}$; four at $5-6 \mathrm{~mm} / \mathrm{s}$ and two greater than $6 \mathrm{~mm} / \mathrm{s}$ ) with the two largest occurring overnight when no video information was available. Even when video information was available, there was no way of using it to determine accurately the characteristics of the wave that caused each event. Consequently, the significant wave height and direction in the 


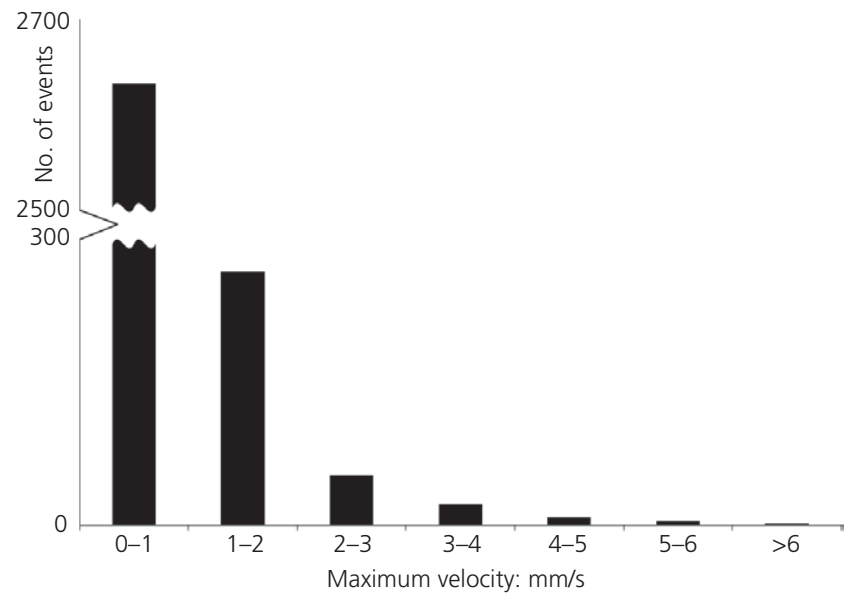

Figure 7. Histogram of the maximum velocity values measured by the geophone

vicinity of the Eddystone reef were assumed to be the same as the hourly estimates available from the E1 buoy and these values were used for most of the subsequent analysis.

The relationship between velocity and significant wave height shown in Figure 8 indicates that there was no clear correlation between these variables. To explain this it is necessary to consider the influence of factors such as the surrounding bathymetry, the local depth of water, the direction of wave approach and characteristics of the waves that ultimately reached the tower.

The local bathymetry was determined by means of a multibeam sonar survey in the summer of 2013 (McAuley, 2013). This confirmed the irregular structure of the reef that climbs steeply from a depth of about $50 \mathrm{~m}$, with some submerged slopes as steep as 1:3 along the southwesterly transect. The water level around the Eddystone reef also varies widely due to the influence of tides, the atmospheric conditions and the presence of swell. In this environment, the size and nature of the waves that reach the lighthouse are determined by a complex interaction of processes such as shoaling, refraction, reflection and breaking. All of the waves that both caused a vibration event and were recorded clearly on video had already broken to some extent before their impact on the tower. Given that the sooner a wave breaks the longer it has to dissipate energy and momentum, it was not surprising to find that the maximum velocities recorded by the geophone tended to increase with the estimated depth of water at the base of the tower, the greater depth tending to delay breaking. Conversely, increasing height and steepness cause waves to break earlier. The bathymetry also had a strong influence on the ability of waves from a particular direction to reach the tower, with analysis showing that the largest tower responses were due to waves approaching

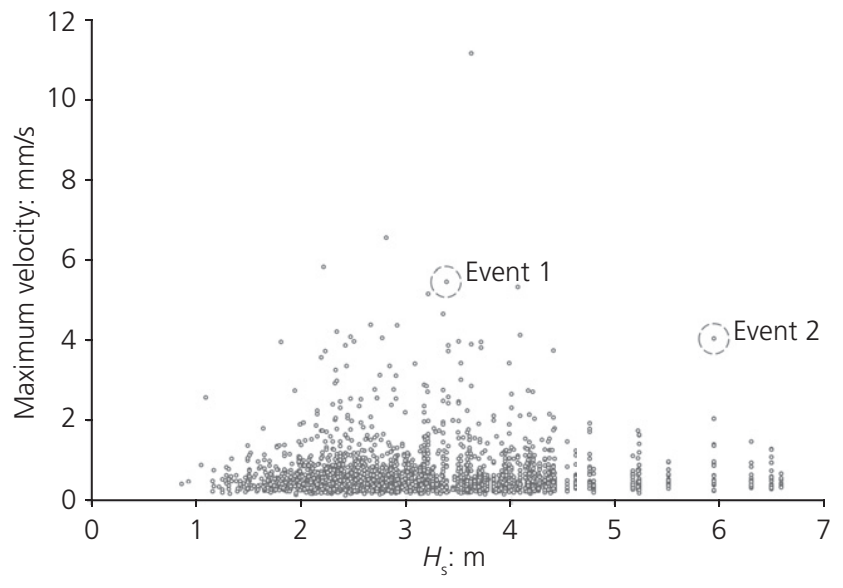

Figure 8. The relationship between maximum velocity and significant wave height

\begin{tabular}{|c|c|c|}
\hline & Event 1 & Event 2 \\
\hline Date & 6 January 2014 & 5 February 2014 \\
\hline $\begin{array}{l}\text { Significant wave } \\
\text { height, } H_{\mathrm{s}}\end{array}$ & $3 \cdot 38 \mathrm{~m}$ & $5.95 \mathrm{~m}$ \\
\hline $\begin{array}{c}\text { Maximum wave } \\
\text { height, } H_{\max }\end{array}$ & $9.02 \mathrm{~m}$ & $15 \cdot 14 \mathrm{~m}$ \\
\hline Peak period, $T_{\mathrm{p}}$ & $11.8 \mathrm{~s}$ & $13 \cdot 3 \mathrm{~s}$ \\
\hline $\begin{array}{l}\text { Water depth at base } \\
\text { of structure }\end{array}$ & $4.52 \mathrm{~m}$ & $6.04 \mathrm{~m}$ \\
\hline Wave direction & $240^{\circ}$ & $233^{\circ}$ \\
\hline
\end{tabular}

Table 3. Wave and depth parameters for events 1 and 2

from bearings between $220^{\circ}$ and $244^{\circ}$, as measured at the E1 buoy.

To shed more light on the wave impacts and structural response, two particular events for which video data exist will now be analysed in more detail. The events are identified in Figure 8 and the prevailing sea conditions are listed in Table 3.

In event 1 an impact was registered even though the wave was of relatively modest size and celerity. Lack of height enabled the wave to break very close to the tower, which it hit fairly low down and with considerable intensity. As can be seen from Figure 9(a), the impact created a great deal of white water at the base of the tower but very little run-up. In fact, were it not for the large structural response measured it would not appear to be a significant impact. 
In event 2 a much larger wave with a greater estimated celerity broke about $30 \mathrm{~m}$ from the tower, thereby creating a much more dispersed impact zone. Figure 9(b) shows the dramatic way in which water rises quickly up the tower to the level of the photovoltaic panels some $40 \mathrm{~m}$ above the structure's cylindrical base. The velocity of the run-up can be estimated by use of the grid described in Section 3.1 to estimate the runup levels in sequential video frames (not all shown in Figure 9 (b)). This gives a maximum of about $50 \mathrm{~m} / \mathrm{s}$ at $16 \mathrm{~m}$ above the cylindrical base (10 $\mathrm{m}$ above the impact zone), reducing to $35 \mathrm{~m} / \mathrm{s}$ at an elevation of about $23 \mathrm{~m}$ above the base. Above this level the camera's view was obscured by the photovoltaic panels, but the rapid deceleration of the jet between the two locations suggests that it would probably have travelled only a little further. At the time of this event, the water near the tower was about $6 \mathrm{~m}$ deep which, on the basis of shallow water wave theory, suggests that the wave celerity prior to impact was around $7.7 \mathrm{~m} / \mathrm{s}$. Use of the latter value together with the guidance in Eurotop (Pullen et al., 2007) enables the vertical velocity of the jet produced when an impulsive wave hits a vertical wall to be estimated. The resultant range of $39-54 \mathrm{~m} / \mathrm{s}$ is compatible with the experimental estimate of $50 \mathrm{~m} / \mathrm{s}$.

Figure 10 shows the temporal variation in the velocity of motion along the principal axis of vibration for events 1 and 2, as recorded by one of the geophones (the other produced virtually identical data). The maximum velocities are about $5.5 \mathrm{~mm} / \mathrm{s}$ and $4 \mathrm{~mm} / \mathrm{s}$, respectively. The response for event 1 , although it was initially the larger of the two, dies down within one data capture window, whereas the response for event 2 was still sufficiently large at the end of the data capture window to trigger further signal acquisition. The reason for this is evident when the displacements are considered, as seen in Figure 11. The displacement time histories clearly show that event 2 is responsible for a significantly larger displacement of $0.069 \mathrm{~mm}$ when compared with $0.033 \mathrm{~mm}$ for event 1 , so its vibration

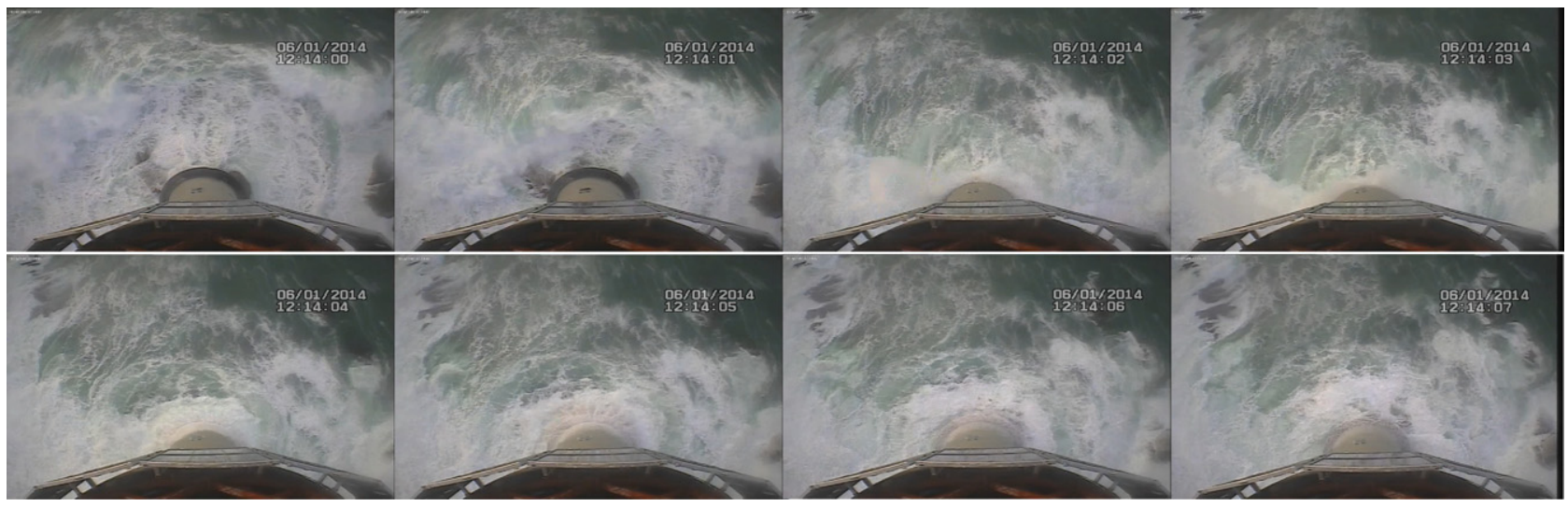

(a)

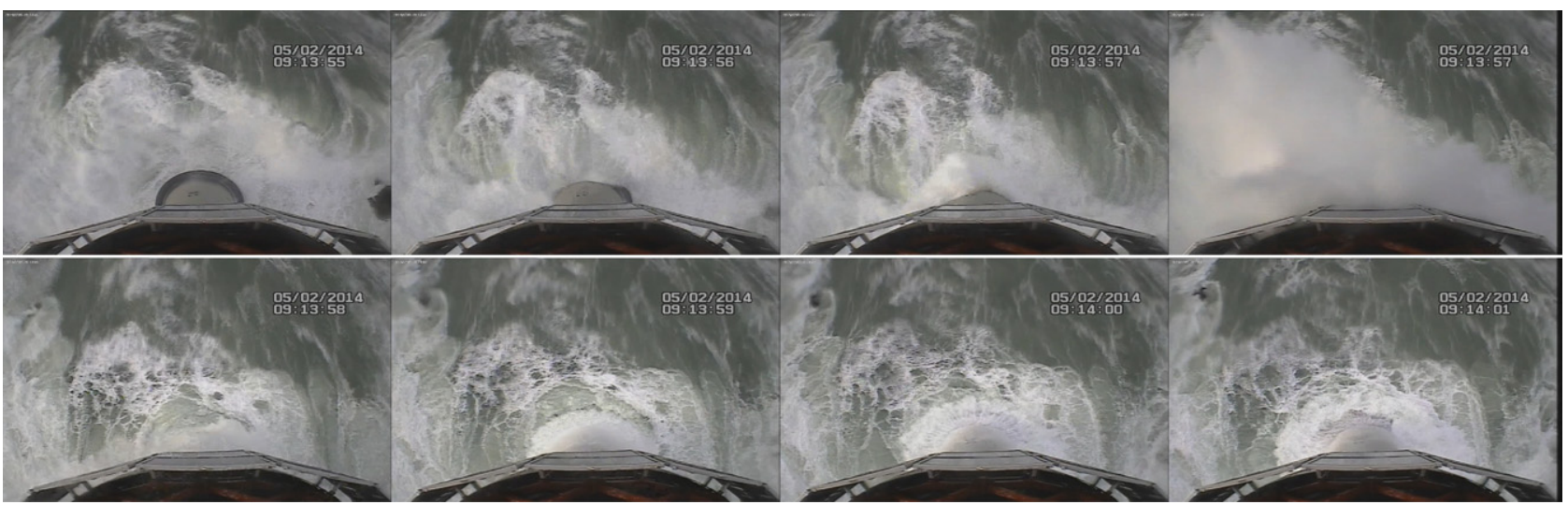

(b)

Figure 9. Time sequence of impacts: (a) event 1 against the base of the tower and (b) event 2 impact and subsequent run-up on the tower 


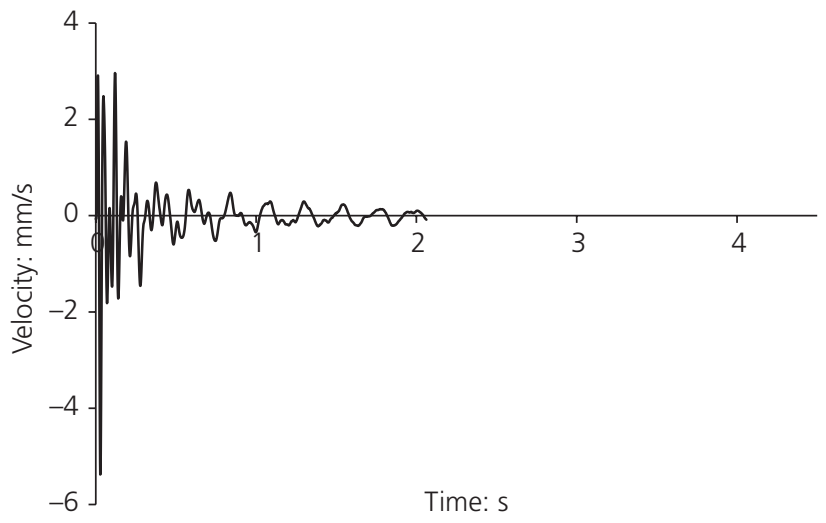

(a)

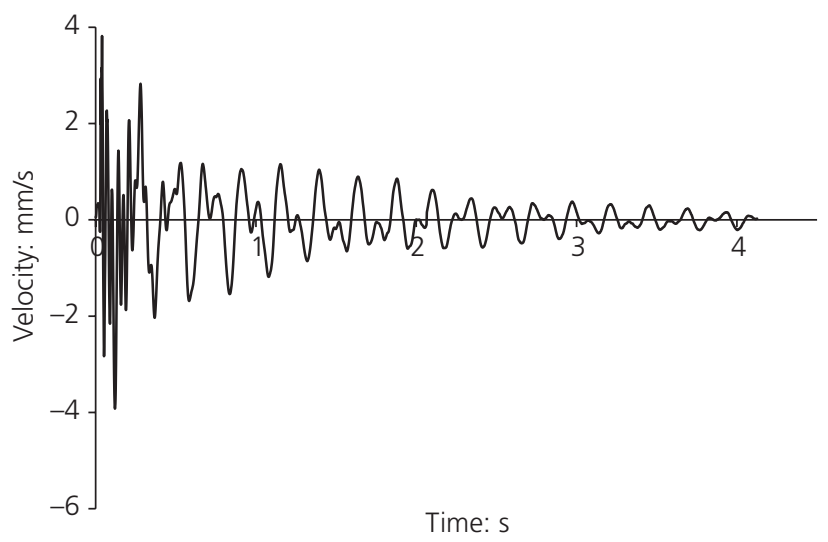

(b)

Figure 10. Geophone sensor no. 1 principal axis velocity time history for: (a) event 1 and (b) event 2

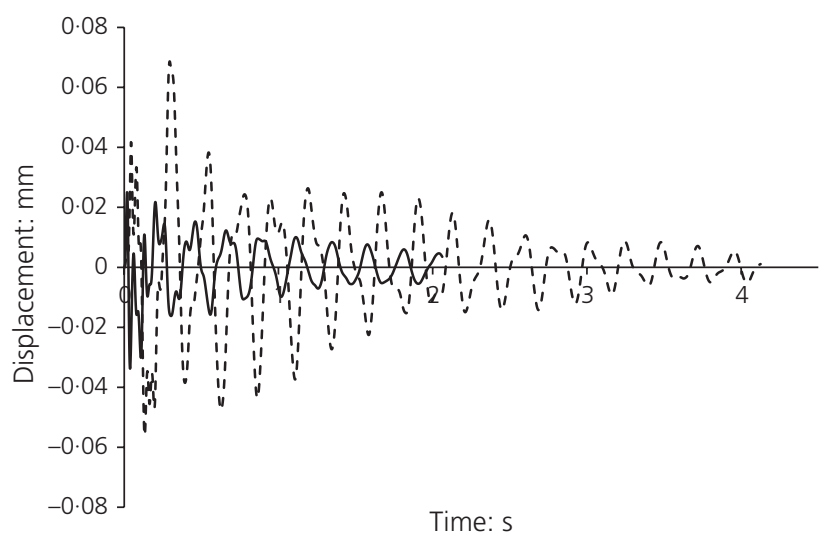

Figure 11. Displacements along the respective principal axes for event 1 (-) and event 2 (- -) motion would indeed be expected to persist for longer assuming that structural damping is similar along the two principal axes.

Linking the angle of vibration to the direction of wave approach as measured at the E1 buoy, data obtained from the principal axis analysis indicate that for event 1 the impact had a bearing of $239^{\circ}$, which is in close agreement with the $240^{\circ}$ obtained for the wave direction from the E1 buoy. In event 2, the bearing of the impact is almost due southwest at $223^{\circ}$, which is a little further from the buoy wave data angle of $233^{\circ}$. This difference is likely to be due to refraction effects around the reef.

Further information can be obtained from the amplitude spectra of the displacements. Figure 12 indicates that there are clear peaks in the spectra corresponding to vibration modes of the structure at $4.4 \mathrm{~Hz}, 8 \cdot 2 \mathrm{~Hz}$ and $15.3 \mathrm{~Hz}$. Event 2 was the more energetic, which is consistent with the motion persisting for longer. However, the vibration at around $15 \mathrm{~Hz}$ was more significant in event 1 than in event 2, possibly due to the magnitude and elevation of the impact exciting this mode.

Finally, the event 1 wave delivered a much cleaner impact to the structure than the event 2 wave. Most of the event 1 impulse seems to have occurred within the first $\sim 0 \cdot 1 \mathrm{~s}$, whereas the event 2 impulse was probably significant for at least twice as long. The different vibration signatures due to these breaking and broken wave examples are entirely consistent with findings from large-scale (1:4) laboratory tests (Bullock et al., 2007), in which broken waves were demonstrated to cause much longer duration impacts than those of breaking waves, and their spatial extent was also much greater.

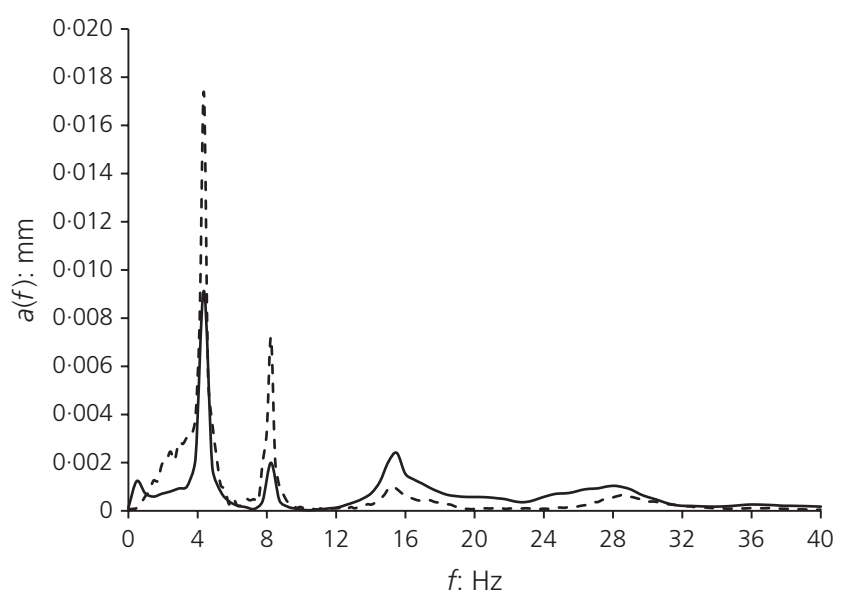

Figure 12. Amplitude spectra of the geophone displacement for event 1 (-) and event 2 (- -) 


\subsection{Finite-element model results}

A modal analysis was undertaken using the FE model with the first mode of the tower initially predicted to be $4 \cdot 7 \mathrm{~Hz}, 0 \cdot 3 \mathrm{~Hz}$ higher than the value shown in Figure 12. Agreement between the FE model and the field data was achieved by decreasing the Young's modulus from the initial mean estimate of $36 \mathrm{GPa}$ to $34 \mathrm{GPa}$. Subsequently, it was discovered that Douglass (1883) made mention of the fact that the Dalbeattie blocks were used to complete the solid portion of the tower, while De Lank blocks were used for the whole of the remainder of the tower, providing further justification for choosing a Young's modulus closer to $32 \mathrm{GPa}$ than $40 \mathrm{GPa}$. The FE model did not exhibit any response near $8 \cdot 2 \mathrm{~Hz}$, although there was a strong response at $15.2 \mathrm{~Hz}$, which is in good agreement with the field value of $15.5 \mathrm{~Hz}$. The reason for the absence of any response at $8 \mathrm{~Hz}$ is currently being investigated, but it may be due to the fact that the lighthouse was modelled as a monolithic structure rather than one comprising mortared blocks. It might also be the case that the geophones are picking up vibrational responses of the complex reef-structure interaction or helideck not considered in the FE analysis.

The effect of wave loading on the tower was investigated by simulating the loading in two phases. The initial phase concerned the impact and was based on the work of Wienke and Oumeraci (2005), which has been incorporated in the international standard 'Actions from wave and currents on coastal structures' (ISO/CD 21650 (ISO, 2007)). This was followed by the application of drag and inertia forces for a wave interacting with a cylinder as described by the Morison equation (Morison et al., 1950). The spatial distribution of loads in the azimuthal direction was described by Wienke and Oumeraci (2005) and a qualitative vertical distribution was based on the work of Kyte and Tørum (1996). Wave parameters used in the formulae were based on the buoy data and typical wave breaking characteristics. Initial tests (Cali, 2014) produced deflections several times greater than those measured in the field, not unsurprising given the difficulty in specifying the characteristics of a particular breaking wave. The most recent results, using a finer mesh with more precise wave loading locations, are showing very good agreement with the geophone results: the maximum displacement is still over-estimated (by about two) but the subsequent oscillations closely match the field data.

An initial stability analysis has also been undertaken with the FE model, based on material failure and overturning collapse. As would be expected, the results indicated that the design of this tower was well within safe limits for that particular wave.

\section{Conclusions and further work}

Occupants of exposed lighthouses during a severe storm report the experience in much the same way now as their forbears did. Similarly, investigators seeking data from these hostile environments still face challenges, although the issues are now ones of data storage and transmission rather than the hazards faced by a lighthouse keeper clambering over rocks to recover each maximum pressure reading. However, despite the lack of electronics, Stevenson's archived data from the marine dynamometer list values that are comparable to some recent field values (Bullock et al., 2007). Significant advances have been made and modern instrumentation enables subjective impressions of structural motion to be complemented by detailed measurements.

Even for the largest wave impacts measured during the 2013/ 2014 storms, the geophone readings taken in the Eddystone Lighthouse indicate that the motion of the tower was smaller than might have been expected after reading the reports mentioned in Sections 2.1.2 and 5.1. Possibly, the current Eddystone Lighthouse responds less than the others. Conversely, while the cylindrical base of the lighthouse may reduce the wave run-up (Douglass, 1883), video data show that it does not prevent water from jetting up to around the level of the photovoltaic panels (where the cameras become submerged) and possibly even obscuring the light. The speed of the highest run-up recorded was well described by recent impulsive jet velocity guidance (Pullen et al., 2007).

Field data have shown the structural response of the lighthouse to be sensitive to the precise nature of the wave loading. An FE model of the tower has been developed and successfully tuned to the first and third modes of vibration measured in the full-scale structure, although the second mode is missing, possibly due to the model being represented as a monolithic structure or because the geophones are picking up the vibrations of the reef or helideck. Attempts to reproduce an example of the full-scale response to wave loading, by the application of empirical formulae adopted in the relevant international standards, have resulted in a slight over-prediction of the displacement. Revised loads based on both physical model tests in the Coastal, Ocean and Sediment Transport laboratory at Plymouth University and a computational study using OpenFoam are currently being determined. The FE model also confirmed the stability of the tower to the wave tested. The stability is further corroborated by the lack of any visible impairment of the structure over the passage of time.

Other ongoing work includes fitting lenses with a smaller field of view to the cameras on the Eddystone to improve the resolution of the waves against the tower; the addition of two further geophones systems at different elevations giving more detailed information on the vibration modes, and the placement of a lower frequency geophone on the more exposed Longships Lighthouse to compare with the Eddystone responses. This multifaceted approach will give further insight 
into event-based structural response and be the next step towards providing a means to identify structures at risk.

\section{Acknowledgements}

The authors would like to acknowledge the support of the General Lighthouse Authorities, particularly Martin Bransby and Ron Blakeley (ex-Trinity House) and their lighthouse engineers who assisted with deployments on station; Peter Ganderton and Tony Tapp of Plymouth University who designed much of the installed equipment; the School of Marine Science and Engineering who funded Davide Banfi's studentship; Professors Bernardino Chiaia and Mauro Corrado from Politecnico di Torino who co-supervised Federico Cali's MSc dissertation; and Mr Gwyn Jones who organised the Eddystone reef survey, supervising Paul McAuley's MSc dissertation at Plymouth University.

\section{REFERENCES}

Bagnold RA (1939) Interim report on wave-pressure research. Journal of the Institution of Civil Engineers 12(7): 202-226.

Bathhurst B (2005) The Lighthouse Stevensons. Harper Perennial, London, UK.

Bird PAD, Crawford AR, Hewson PJ and Bullock GN (1998) An instrument for field measurement of wave impact pressures and seawater aeration. Coastal Engineering 35(1-2): 103-122.

Blenkinsopp CE and Chaplin JR (2011) Void fraction measurements and scale effects in breaking waves in freshwater and seawater. Coastal Engineering 58(5): 417-428.

Bredmose H, Skourup J, Hansen EA et al. (2006) Numerical reproduction of extreme wave loads on a gravity wind turbine foundation. In 25th International Conference on Offshore Mechanics and Arctic Engineering (OMAE2006). Volume 1: Offshore Technology; Offshore Wind Energy; Ocean Research Technology; LNG Specialty Symposium. American Society of Mechanical Engineers (ASME), New York, NY, USA, pp. 279-287.

Bredmose H, Peregrine DH and Bullock GN (2009) Violent breaking wave impacts. Part 2: modelling the effect of air. Journal of Fluid Mechanics 641: 389-430.

Bredmose H, Bullock GN and Hogg AJ (2015) Violent breaking wave impacts. Part 3. Effects of scale and aeration. Journal of Fluid Mechanics 765: 82-113.

Bullock G and Bredmose H (2010) Breaking wave impacts on coastal structures. Proceedings of the 5th Annual Conference on Advances in Computing and Technology, University of East London, London, UK, pp. 17-26.

Bullock GN, Crawford AR, Hewson PJ, Walkden MJA and Bird PAD (2001) The influence of air and scale on wave impact pressures. Coastal Engineering 42(4): 291-312.
Bullock GN, Obhrai C, Peregrine DH and Bredmose $\mathrm{H}$ (2007) Violent breaking wave impacts. Part 1: results from large-scale regular wave tests on vertical and sloping walls. Coastal Engineering 54(8): 602-614.

Cali F (2014) Finite Element Model of the Eddystone Lighthouse. MSc dissertation, Plymouth University, Plymouth, UK.

Capurso M (1971) Lezioni di Scienza delle Costruzioni. Pitagora, Bologna, Italy, pp. 402-417 (in Italian).

CCO (Channel Coastal Observatory) (2014) Regional Coastal Monitoring Programmes. CCO, Penzance, UK. See http:// www.channelcoast.org/data_management/real_time_data/ charts/?chart=75 (accessed 11/07/2014).

Chan E, Cheong H and Tan B (1995) Laboratory study of plunging wave impacts on vertical cylinders. Coastal Engineering 25(1-2): 87-107.

Clough RW and Penzien J (1993) Dynamics of Structures, 2nd edn. McGraw-Hill, Inc, New York, NY, USA.

De Vos L, Frigaard P and De Rouck J (2007) Wave run-up on cylindrical and cone shaped foundations for offshore wind turbines. Coastal Engineering 54(1): 17-29.

Douglass JN (1878) Note on the Eddystone Lighthouse. Minutes of the Proceedings of the Institution of Civil Engineers 53(Part 3): 247-248.

Douglass WT (1883) The new Eddystone Lighthouse. Minutes of the Proceedings of the Institution of Civil Engineers 75(Part 1): 20-60.

Draper L (1991) Wave Climate Atlas of the British Isles. HMSO, London, UK.

Goda Y (2010) Random Seas and the Design of Maritime Structures, 3rd edn. World Scientific, London, UK.

ISO (2007) ISO 21650:2007: Actions from waves and currents on coastal structures. International Organization for Standardization, Geneva, Switzerland.

Kyte A and Tørum A (1996) Wave forces on vertical cylinders upon shoals. Coastal Engineering 27(3-4): 263-286.

Lykke Andersen T, Frigaard P, Damsgaard ML and De Vos L (2011) Wave run up on slender piles in design conditions model tests and design rules for offshore wind. Coastal Engineering 58(4): 281-289.

Majdalany F (1959) The Red Rocks of Eddystone. Longmans, London, UK.

Mase H, Kosho K and Nagahashi S (2001) Wave runup of random waves on a small circular pier on a sloping seabed. Journal of Waterway, Port, Coastal and Ocean Engineering 127(4): 192-199.

McAuley P (2013) Investigation into the Bathymetry of the Eddystone Reef for Use in Modelling Wave Loading at the Base of the Lighthouse. MSc dissertation, Plymouth University, Plymouth, UK.

Met Office (2013) Autumn Storm, October 2013. Met Office, Exeter, UK. See http://www.metoffice.gov.uk/climate/uk/ interesting/2013-octwind (accessed 17/07/2014). 
Morison JR, O'Brien MP, Johnson JW and Schaaf SA (1950)

The force exerted by surface waves on piles. Petroleum

Transactions (American Institute of Mining

Engineers) 189: 149-154, http://dx.doi.org/10.2118/ 950149-G.

Oumeraci H (1994) Review and analysis of vertical breakwater failures - lessons learned. Coastal Engineering 22(1-2): 3-29.

Owens D (2014) Cornwall winter events 2013/14. ICE South West: Coastal Defences Meeting the Challenge. New Continental Hotel, Plymouth, 4 April.

Planning Portal (2010) PPS25: Planning Policy Statement 25: Development and Flood Risk. See http://www.planningportal. gov.uk/planning/planningpolicyandlegislation/ previousenglishpolicy/ppgpps/pps25 (accessed 15/09/2015).

Pullen T, Allsop NWH, Bruce Tet al. (2007) EurOtop: Wave Overtopping of Sea Defences and Related Structures: Assessment Manual. HR Wallingford, Wallingford, UK. See http://www.overtopping-manual.com (accessed 15/09/2015).
Stevenson A (1848) Account of the Skerryvore Lighthouse with Notes on the Illumination of Lighthouses. Adam and Charles Black, Edinburgh, UK.

Stevenson R (1824) An Account of the Bell Rock Light-House Including the Erection and Peculiar Structure of that Edifice. Archibald Constable \& Co, Edinburgh, UK.

Timoshenko SP and Goodier JN (1951) Theory of Elasticity, 2nd edn. MacGraw Hill Inc, Tokyo, Japan.

Trinity House (2014) Lighthouses. Trinity House, London, UK. See http://www.trinityhouse.co.uk/mariner_info/aids_to_ navigation/lighthouses.html (accessed 09/01/2015).

Trinity House (2015) Eddystone. Trinity House, London, UK. See http://www.trinityhouse.co.uk/lighthouses/lighthouse_ list/eddystone.html (accessed 27/05/2015).

Wienke J and Oumeraci H (2005) Breaking wave impact force on a vertical and inclined slender pile - theoretical and large scale model investigations. Coastal Engineering 52(1): 435-462.

Winstanley H (1699) Eddystone Lighthouse, Narrative of the Building. HM Treasury, London, UK, Calendar of Treasury Papers, 1702-7.

\section{WHAT DO YOU THINK?}

To discuss this paper, please email up to 500 words to the editor at journals@ice.org.uk. Your contribution will be forwarded to the author(s) for a reply and, if considered appropriate by the editorial panel, will be published as discussion in a future issue of the journal.

Proceedings journals rely entirely on contributions sent in by civil engineering professionals, academics and students. Papers should be 2000-5000 words long (briefing papers should be 1000-2000 words long), with adequate illustrations and references. You can submit your paper online via www.icevirtuallibrary.com/content/journals, where you will also find detailed author guidelines. 